сформулировать следующие выводы: студенты все больще времени тратят на просмотр происходящего в сетях; социальные сети являются одним из самых быстрых средств обмена информацией между студентами; наличие аккаунта в социальных сетях облегчает связь студентов с людьми, которые живут далеко от них; происходящее в сети может негативно влиять на частную жизнь и профрессиональное развитие студентов, если они пренебрегают этикой поведения в сети.

Ключевые слова: электронные сочиальные сети, реальность, виртуальный мир, этика поведения, зависимость от сети.

удк 530.145

Ірина Клімова

Харківський національний автомобільно-дорожній університет ORCID ID 0000-0003-1965-8577

Лариса Ричкова Харківський національний автомобільно-дорожній університет ORCID ID 0000-0003-2052-0196 DOI 10.24139/2312-5993/2019.08/077-086

\title{
МЕТОДИЧНИЙ МАЙСТЕР-КЛАС В КРЕАТИВНОЇ ШКІЛЬНОЇ МАТЕМАТИЧНОЇ ПІДГОТОВКИ РОЗДІЛУ «ЕЛЕМЕНТИ КОМБІНАТОРИКИ ТА ТЕОРІЇ ЙМOBIPHOCTI»
}

Проблема технічного й освітнього забезпечення середньої та вищої школи постає з кожним днем усе серйозніше. Україна готується повністю реформувати свою політику заради того, щоб стати самостійним учасником міжнародних відносин. Це потребуватиме вдосконалення існуючої системи освіти, а для цього потрібно пройтись не лише по очевидних частинах чієї системи, як-то вдосконалити систему кадрового відбору та оснастити навчальні заклади передовою технікою, але й піти далі та замінити застарілі аспекти у викладанні математичних дисииплін. Це дослідження має теоретично, а потім $i$ експериментально, довести, що, по-перше, проблеми в «сучасній» методиці викладання таки $\epsilon$, по-друге, вони мають шляхи рішення, які можуть бути впроваджені на базі будь-якого закладу освіти силами викладачів, які в ньому працюють. Звичайно, що в межах однієї праці неможливо розглянути всі наявні питання, тож ми проаналізували лише деякі, що, на наш погляд, найбільше потребують негайного вирішення.

Ключові слова: комбінаторика, проблема, навчальний заклад, елемент комбінаторики, умови існування

Постановка проблеми. Проблема технічного й освітнього забезпечення середньої та вищої школи постає з кожним днем усе серйозніше. Україна готується повністю реформувати свою політику заради того, щоб стати самостійним учасником міжнародних відносин. Це потребуватиме вдосконалення існуючої системи освіти, а для цього потрібно пройтись не лише по очевидних частинах цієї системи, як-то вдосконалити систему кадрового відбору та оснастити навчальні заклади передовою технікою, але й 
піти далі та замінити застарілі аспекти у викладанні математичних дисциплін. Це дослідження має теоретично, а потім і експериментально, довести, що, поперше, проблеми в «сучасній» методиці викладання таки $€ \mathrm{i}$, по-друге, вони мають шляхи рішення, які можуть бути впроваджені на базі будь-якого закладу освіти силами викладачів, які в ньому працюють. Звичайно, що в межах однієї праці неможливо розглянути всі наявні питання, тож ми проаналізували лише деякі, що, на наш погляд, найбільше потребують негайного вирішення.

Мета статті - аналіз та пошук можливих шляхів вирішення деяких проблем, пов'язаних із математичними дисциплінами.

Методи досліджень, основним серед яких був і залишається аналіз останніх досліджень та публікацій, а також статистичних даних опитувань і спостережень наших колег, за допомогою яких ми досягнемо цієї мети.

\section{Виклад основного матеріалу.}

\section{1. Комбінаторика. Елементи комбінаторики (приклади 1-3).}

Загалом важко переменшити значення математики як дуже важливого інструменту в розвиткові дослідницьких форм мислення школяра або студента. Натомість беззаперечним фактом також $\epsilon$ те, що зміст науки та традиційні методики вимагають значного збільшення ролі дослідницьких завдань і методів навіть у розкритті загальновідомих шкільних тем. Ми сьогодні опустимо людський фактор, тобто якість та зміст професійної підготовки вчителів та сучасну систему виховання дітей. Звернемо увагу на нерозробленість загальновідомих якісних і доступних методик навчання вирішенню задач, які розвивають в учнів закладів загальної середньої освіти продуктивний рівень засвоєння навчального матеріалу (Кудрявцев, 1998).

Перш ніж робити висновки з проаналізованих досліджень, треба визначитися з поняттям «комбінаторика». Це розділ математичної науки, яким досліджується кількість різних комбінацій (усіх можливих об'єднань елементів), підпорядкованих тим чи іншим умовам, які цілком можна скласти з елементів, що належать даній множині.

Однією з основних проблем під час вивчення розділу «Комбінаторика» як у шкільному, так і у вишівському середовищі - це недостатня увага до умов існування елементів комбінаторики. Особливо гостро це відчувається під час вирішення рівнянь та нерівностей, які мають комбінаторні вирази, що містять невідомі: $C_{x}^{x-3}, P_{x}, A_{x+2}^{x}$ тощо (Дубовик, 2006). Одразу ж варто згадати про значення терміну «елемент комбінаторики». Це, по-перше, принципи, тобто правила комбінаторики, які й обумовлюють існування їі елементів. Це правило суми (якщо множина А містить $\mathrm{n}$ елементів, а множина В tелементів і $A \cap B=\varnothing$, то множина AUB містить $n+t$ елементів) та правило добутку (загальний вигляд: нехай треба одну за одною виконати k дій; якщо першу дію можна виконати $\mathrm{n}$ способами, другу - $\mathrm{n}_{2}$ способами і так - до k - 
тої, відповідно - $\mathrm{k}$ способами, то всі $\mathrm{k}$ дій разом можуть бути виконані $\mathrm{n}$ способами, де $\mathrm{n}=\mathrm{n}_{1} \cdot \mathrm{n}_{2} \cdot \ldots \cdot \mathrm{n}_{\mathrm{k}} \cdot$ ), по-друге, перестановки, які являють собою будь-які впорядковані множини, що складаються з $\mathrm{n}$ елементів, потретє, розміщення - підмножини, які мають певну кількість елементів, які обрано з більшої кількості та розміщено в певному порядку, по-четверте, комбінації, підмножина з визначеної кількості елементів даної в умові множини, яка містить означену кількість елементів (Дубовик, 2006; Кудрявцев, 1998).

Метою даного дослідження є спроба наочно привчити учнів старших класів та студентів починати працювати з комбінаторними рівняннями та нерівностями з аналізу умов існування. Наприклад:

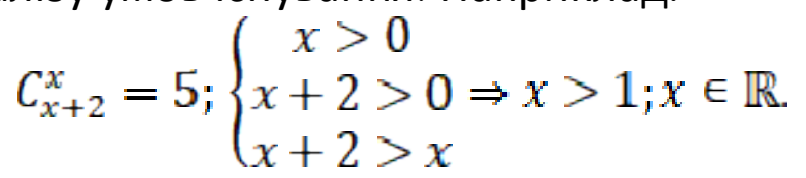

У сучасній теорії навчання математиці одним із прийомів творчого та евристичного типу продуктивних дій учнів стали саме завдання 3 параметрами, які, на думку провідних учених, $\epsilon$ природним етапом у вирішенні будь-якої математичної задачі. Актуальність цього питання обумовлена необхідністю створення цілісної методики навчання, яка 6 містила забезпечення розвитку в учнів продуктивного рівня засвоєння навчального матеріалу з багатьох тем, у тому числі - «Вирішення рівнянь та нерівностей» (Коваленко, 2006).

Наразі нашою наукою рівняння з параметром ставляться в один ряд із квадратними, дробовими, логарифмічними, тими, що містять модуль тощо (Бугров и Никольский, 1984). Це невірно. Адже параметризувати можна будьяку математичну задачу, відповідно всі рівняння й нерівності можна розподілити на дві групи: без параметрів та з параметрами, тож це більш змістовна категорія, ніж наразі вважається. Виходячи з сутності завдань із параметрами, їх рішення за своєю сутністю $€$ якісним узагальненням навчального досвіду учня на більш високому продуктивному рівні діяльності, тому технологія вирішення таких задач повинна бути чітко оговорена, повинні бути розібрані приклади й наведена система вправ.

У школяра поняття рівняння з параметром має включати в себе розуміння таких фактів:

- рівняння та нерівності 3 параметром - це клас рівнянь та нерівностей одного виду за одних значень параметру, інших видів - за інших значень параметру, за якихось значень параметра до цього класу входять вірні або нерівні тотожності (числові нерівності). Наприклад, рівняння $(a-2) \sqrt{x+1}=(a+2) x \quad$ за $a=-2 \quad$ стає простим ірраціональним: якщо $a \neq 2,-2$ - рівняння ірраціональне;

- вирішення рівняння або нерівності може включати в себе декілька методів вирішення, які відповідають кожному виду рівняння за певних 
значень параметру. Наприклад, за якого значення параметру нерівність лінійна, тож вирішуємо ії аналітично тотожними перетвореннями; за решти значень параметру нерівність квадратична - вирішуємо ії функціональнографічним способом (Бугров и Никольский, 1984; Дубовик, 2006; Герасимчук, 2010; Кудрявцев, 1998).

Власне, на нашу думку, одним із шляхів вирішення проблеми також стане виділення п'яти рівнів підготовки учня за темою «Рівняння та нерівності»:

1) уміння вирішувати найпростіші рівняння й нерівності;

2) уміння вирішувати рівняння та нерівності, які мають бути приведені до найпростіших, шляхом «нескладних» тотожних перетворень (додавання числа до обох частин рівняння або нерівності, поділ обох частин рівняння чи нерівності на число, приведення до спільного знаменника, приведення подібних тощо);

3) уміння вирішувати найпростіші рівняння та нерівності 3 параметрами і рівняння або нерівності, які приводяться до них шляхом «нескладних» тотожних перетворень;

4) уміння вирішувати рівняння та нерівності, що приводяться до найпростіших шляхом «складних» тотожних перетворень (використання формул скороченого множення, заміни змінної, розкладення на множники, властивостей функції та її графіку тощо);

5) уміння вирішувати рівняння та нерівності з параметрами, що приводяться до найпростіших шляхом «складних» перетворень.

Даний шлях, на наш погляд, є якщо не готовим шляхом до вирішення викладеної вище проблеми, то вже точно стане вирішальним кроком на цьому шляху, бо, як ми з'ясували, корінь проблеми полягає в недостатньо серйозному ставленні до даної проблеми та навіть у тому, що це не вважається проблемою взагалі.

\section{2. Теорія імовірності (приклад 4).}

Не дивлячись на те, що дана тема, на перший погляд, видається досить нескладною, особливо в школі, через те, що її вивченню на початкових етапах не надається потрібної уваги, у студентів виникають проблеми з розуміннями навіть найелементарніших питань та проблем. Як казав Карл Пірсон: «Нема теми для помилок улюбленішої, ніж теорія імовірностей». Причиною цьому, певно, $€$ те, що деякі висновки спираються більше на так званий здоровий глузд, аніж на математичний підхід. Як ми вже зазначали, усі проблеми в даній статті висвітлити ми не можемо через наявність чіткого регламенту, але оберемо, на наш погляд, максимально важливу.

Такою ми вважаємо загальну шкідливу тенденцію, за якої багато вчителів математики часто переоцінюють роль комбінаторики у викладанні теорії ймовірності. Нерідко викладач спочатку формально викладає комбінаторні факти та формули, а потім пропонує задачі, які містять термін «імовір- 
ність» у якості прикладу застосування. Найчастіше що у вишах, що в загальноосвітніх школах теорія імовірності викладається лише як додаток до комбінаторики. На наш погляд, виховання імовірнісного сприйняття важливіше, ніж проведення паралелей, які можуть закривати шлях до розвитку математичної творчої думки. На нашу думку, у викладанні теорії імовірності комбінаторика грає дуже важливу, але все ж допоміжну роль. Вона обумовлена ситуаціями, коли імовірнісні простори дуже широкі та без комбінаторики обійтися неможливо (Бугров и Никольский, 1984; Герасимчук, 2010; Кудрявцев, 1998).

Найкращий приклад для демонстрації цієї проблеми - це тема «Прогнози». Для їі ілюстрації можна подивитися на приклад № 4. Так, з точки зору теорії задача вирішена абсолютно вірно. Але згадаємо, знов-таки, проблему здорового глузду. Багато факторів не враховуються під час вирішення:

мова йде про поламку протягом якогось визначеного терміну, наприклад, гарантійного;

неявно мається на увазі, що скаржитися будуть виключно ті, у кого зламається комп'ютер, але не враховується, що деякі з них, наприклад, можуть просто мовчки купити собі новий або викинути зламаний, а також просто звернутися в якийсь кустарний сервіс.

Навіть абстрагуючись від нечіткої умови, доводиться визнати, що завдання поставлене невірно та некоректно, тож відповідь може бути лише одна - невідомо, яка фірма отримає більше скарг. Як же можна коректно вирішити дану задачу?

Помилка схована в механічному підході автора до імовірнісного питання, видаючи математичні очікування величин за їх достовірні значення. Справді ж комп'ютерів зламається рівно стільки, скільки зламається, а клієнтів зі скаргами буде рівно стільки, скільки буде. Парадокс? Аж ніяк, бо насправді 144 та 135 - це не більш, ніж математичні очікування величин, себто середні теоретичні значення. Інтуїтивно ми розуміємо, що невдоволених клієнтів у першої фірми повинно бути більше. Це навіть можна довести, але також інтуїція каже, що середні 144 та 135 досить близькі одне до одного, а розсіювання обох величин значне, тож теоретично невдоволених клієнтів у другої фірми може бути більше. Розрахунок демонструє, що імовірність події $x_{1}>x_{2}$ дорівнює 0,696, імовірність події $x_{1}<x_{2}$ дорівнює 0,283, і є ще подія $x_{1}=x_{2}$, імовірність якої дорівнює 0,021. Якщо подію $x_{1}=x_{2}$ (скаржників порівну) можна сбр відкинути якк малоімовірну, то подія $x_{1}<x_{2}$ (скарг більше у другої фірми) цілком імовірно $(0,283)$. Не можна впевнено стверджувати, що в першої фірми скарг буде більше.

У прикладі під номером 5 ця ситуація також наявна, хоча й меншою мірою. Правильне рішення насправді ніколи не може бути точним числом, що відображає хоч і зроблена за всіма правилами, але й правильна з точки здорового глузду відповідь. Вона приблизна, бо на будь-яку ситуацію, що стосується людей, має свій вплив так званий людський фактор, через який пе- 
редбачити реальний перебіг речей дуже важко, якщо не сказати - неможливо, тож адекватним виходом залишається надання приблизного результату.

Висновки. Нами були проаналізовані як старі, так і найновітніші джерела для визначення проблем, аналізу яких вимагає тема даної статті. Своє завдання ми виконали, спираючись на проаналізовану інформацію та реальний досвід. Вирішення проблем, пов'язаних із комбінаторикою, нами викладене докладно, шлях цього вирішення прописаний максимально чітко та, за винятком деяких нюансів, полягає в більш серйозному ставленні до такої теми, як «Рівняння та нерівності із параметрами». Схожий, але за сутністю відмінний шлях рішення ми пропонуємо для вирішення основної проблеми теорії імовірності: для всіх ситуацій, пов'язаних із людським фактором, надавати лише приблизні результати, які будуть охоплювати максимальну кількість найбільш можливих фіналів викладеної ситуації.

Перспективи подальших наукових розвідок. Загалом дана тема була й залишається відкритою для будь-яких наукових досліджень та експериментів, тож, на нашу думку, у майбутньому ті вчені, які цікавляться нею, матимуть змогу зробити власні практичні, теоретичні та методичні відкриття в цій галузі.

\section{Додаток: «Приклади»}

1. Вирахувати $\frac{3 C_{69}^{27}}{C_{70}^{45}-C_{69}^{44}}$;

Згідно з визначенням кількість сполук з $\mathrm{n}$ елементів по $\mathrm{m}$ елементах

$$
\begin{aligned}
& C_{n}^{m}=\frac{n !}{m !(n-m) !} \text {, де } n, m \in \mathbb{Z} ; n>m ; n, m>0 \\
& \frac{3 C_{69}^{27}}{C_{70}^{45}-C_{69}^{44}}=\frac{3 \cdot 69 !}{27 ! 42 !\left(\frac{70 !}{45 ! 25 !}-\frac{69 !}{44 ! 25 !}\right)}=\frac{3 \cdot 69 !}{27 ! 42 !\left(\frac{69 ! \cdot 70}{45 ! 25 !}-\frac{69 !}{44 ! 25 !}\right)} \\
& \quad=\frac{27 ! 42 ! \frac{69 !}{44 ! 25 !}\left(\frac{70}{45}-1\right)}{27 !}= \\
& =\frac{3 \cdot 44 ! \cdot 25 !}{27 ! \cdot 42 ! \cdot \frac{255}{459}}=\frac{3 \cdot 42 ! \cdot 43 \cdot 44 \cdot 25 ! \cdot 9}{25 ! \cdot 26 \cdot 27 \cdot 42 ! \cdot 5}=\frac{43 \cdot 22}{22}=\frac{946}{65}
\end{aligned}
$$

2. Вирішити рівняння

$$
\begin{gathered}
\frac{P_{x+2}}{A_{x-1}^{x-4} \cdot P_{3}}=210 \\
\text { За визначенням }\left\{\begin{array}{l}
x+2>0 \\
x-1>0 \Rightarrow x>4 \\
x-4>0
\end{array}\right. \\
x \in(4 ;+\infty) \\
\frac{(x+2) !}{(x-1) !}=210 \\
\frac{(x-1-x+4) !}{(x-1-3 !}
\end{gathered}
$$




$$
\begin{gathered}
\frac{(x-1) !(x+1)(x+2) \cdot x}{(x-1) ! \frac{3 !}{3 !}}=210 \\
\left(x^{2}+3 x+2\right) x=210 \\
x^{3}+3 x^{2}+2 x-210=0
\end{gathered}
$$

Ділителі числа 210:

$125+75+10-210=0$

$$
\begin{gathered}
\pm 2 ; \pm 3 ; \pm 7 ; \pm 5 ; \\
x_{1}=5
\end{gathered}
$$$$
\Rightarrow(x-5)-\text { ділитель } x^{3}+3 x^{2}+2 x-210 \text { без залишку }
$$

Ділимо

$x^{2}+8 x+42$

$$
\left.\begin{gathered}
\frac{x^{3}+3 x^{2}+2 x-210}{\frac{x^{3}-5 x^{2}}{8 x^{2}+2 x}} \\
\frac{8 x^{2}-40 x}{42 x-210} \\
\frac{42 x-210}{0}
\end{gathered}\right|^{\frac{x-5}{x^{2}+8 x+42}}
$$

$\neq 0(D=16-42=-26<0)$

- дійсних коренів не має.Єдине вирішення:

$$
x=5 ; 5 \in(4 ;+\infty) \text {. }
$$

3. Вирішити нерівність

$$
A_{x}^{3}+C_{x}^{x-2} \leq 14 x
$$

За умовою $x>3 ; x-2>0 ; x>0 \Rightarrow x>3$

$$
x \in(3 ;+\infty)
$$

$$
\begin{gathered}
\frac{x !}{(x-3) !}+\frac{x !}{(x-2) !(x-x+2) !} \leq 14 x \\
2(x-1)(x-2) x+(x-1) x-28 x \leq 0 \\
x(2(x-1)(x-2)+x-1-28) \leq 0 \\
x\left(2 x^{2}-6 x+4+x-29\right) \leq 0 \\
x\left(2 x^{2}-5 x-25\right) \leq 0 \\
2 x \cdot(x-5)\left(x+\frac{5}{2}\right) \leq 0
\end{gathered}
$$

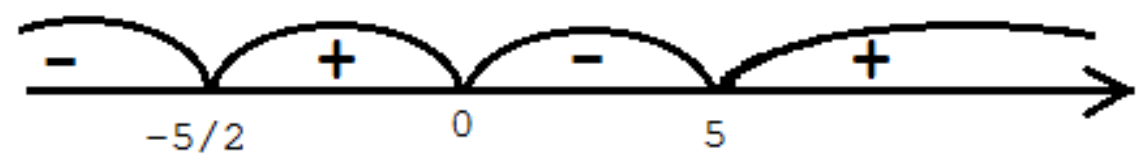




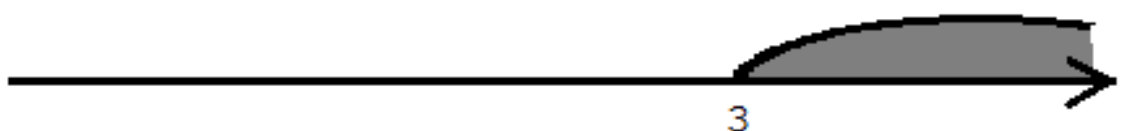

$$
\begin{gathered}
x \in(3 ; 5] \\
x \in \mathbb{Z} \Rightarrow x_{1}=4 ; x_{2}=5 .
\end{gathered}
$$

4. Дві фірми збирають комп'ютери з комплектуючих деталей. Перша фірма збирає неякісні комп'ютери, імовірність їхньої поламки дорівнює 2,4 \%. Друга фірма збирає комп'ютери з якісних деталей. Імовірність їхньої поламки дорівнює 0,6\%. Перша фірма продала 6000 комп'ютерів. Друга фірма - 22500 комп'ютерів. Яка фірма отримає більше скарг на якість?

Вирішення.

$x_{1}$ - кількість несправних комп'ютерів першої фірми, $x_{2}$ - другої фірми. Тоді

$$
\frac{x_{1}}{6000}=0,024 ; \frac{x_{2}}{22500}=0,006 . \text { Отже, } x_{1}=144 ; x_{2}=135, x_{1}>x_{2} \text {. }
$$

5. Серед 26 деталей, що піддаються перевірці, 15 точних. Знайти імовірність того, що серед 11 на удачу витягнутих деталей 8 точних.

Вирішення.

Подія А: серед 11 відібраних деталей 8 точних.

$P(A)=\frac{m}{n} ; n=C_{26}^{11}$ - загальне можливе число комбінацій із 26 по 11.

$C_{15}^{8}$ - число можливих комбінацій 8 точних деталей з 15 точних.

$C_{11}^{3}$ - число можливих комбінацій, залишилися 3 неточних із тих, що залишилися, 11 неточних.

$$
\begin{gathered}
m=C_{15}^{8} \cdot C_{11}^{3} \\
P(A)=\frac{C_{15}^{8} \cdot C_{11}^{3}}{C_{26}^{11}}=\frac{15 ! 11 !}{8 ! 7 ! 8 ! 3 ! \frac{26 !}{11 ! 15 !}}= \\
=\frac{15 ! 11 ! \cdot 11 ! \cdot 15 !}{26 ! 8 ! 7 ! 8 ! 3 !}=\frac{9 \cdot 10 \cdot 11 \cdot 9 \cdot 10 \cdot 11 \cdot 8 \cdot 9 \cdot 10 \cdot 11 \cdot 12 \cdot 13 \cdot 14 \cdot 15}{16 \cdot 17 \cdot 18 \cdot 19 \cdot 20 \cdot 21 \cdot 22 \cdot 23 \cdot 24 \cdot 25 \cdot 2613 \cdot 6} \\
=\frac{121 \cdot 27 \cdot 5}{17 \cdot 16 \cdot 19 \cdot 23 \cdot 13}=\frac{16331}{2046222} \approx 0,0073
\end{gathered}
$$

\section{ЛITEPATУРA}

Кудрявцев, Л. Д. (1998). Краткий курс математичного аналізу. Висагинас: Alfa. Т. 1 (Kudriavtsev, L. D. (1998). Short course of mathematical analysis. Visaginas: Alfa. Vol. 1). Пискунов, Н. С. (1978). Диффреренциальное и интегральное исчисление. М. Наука. Т. 1 (Piskunov, N. S. (1978). Differential and integral calculus. M. Science. Vol.1).

Дубовик, В. П., Юрик І. І. (2006). Вища математика. Вища школа (Dubovyk, V. Р., Yuryk, I. I. (2006). Higher mathematics. Higher school). 
Герасимчук, В. С., Васильченко, Г. С., Кравцов, В. І. (2010). Вища математика. Повний курс у прикладах і задачах. Київ: Книги України. Т. 1-3 (Herasymchuk, V. S., Vasylchenko, H. S., Kravtsov, V. I. (2010). Higher mathematics. Complete course in examples and tasks. Kyiv: Books of Ukraine. Vol. 1-3).

Бугров, В. С., Никольский, С. М. (1984). Элементы линейной алгебры и аналитической геометрии. М.: Наука (Bugrov, V. S., Nikolskii, S. М. (1984). Elements of linear algebra and analytic geometry. M.: Science).

Коваленко, І. П. (2006). Вища математика. Київ: Вища школа (Kovalenko, І. Р. 2006). Higher mathematics. Kyiv: Higher school).

\section{PEЗЮME}

Климова Ирина, Рычкова Лариса. Методический мастер-класс по школьной математической подготовке раздела «Элементы комбинаторики и теории вероятности».

Проблема технического и образовательного обеспечения средней и высшей школы становится с каждым днём все более серьёзной. Украина готовится полностью реформировать свою политику ради того, чтоб стать самостоятельным участником международных отношений. Это требует усовершенствования уже существующей системы образования, для чего нужно пройтись не только по очевидным частям этой системы, в частности, усовершенствовать систему подбора кадров и оснастить учебные заведения передовой техникой, но и пойти дальще и заменить устаревшие аспекты в преподавании математических дисциплин. Это исследование должно доказать вначале теоретически, а впоследствии и экспериментально, что, во-первых, проблемы в «современной» методике преподавания всё-таки есть, и, во-вторых, они имеют пути решения, которые могут быть внедрены на базе любого учебного заведения силами работающих в нём преподавателей. Разумеется, в рамках одного труда невозможно рассмотреть все имеющиеся вопросы, поэтому мы проанализировали лишь некоторые, которые, на наш взгляд, наиболее подходят для немедленного решения.

Ключевые слова: комбинаторика, проблема, учебное заведение, элемент комбинаторики, условия существования.

\section{SUM M ARY}

Klimova Iryna, Rychkova Larysa. Methodical master class on school mathematical preparation of the section "Elements of combinatorics and probability theory."

The problem of technical and educational support for secondary and higher education is becoming more and more serious. Ukraine is preparing to completely reform its policy in order to become an independent participant in international relations. This will require improvement of the existing education system, for which it is necessary to go through not only the obvious parts of this system, in particular, to improve the personnel selection system and equip education institutions with advanced technology, but also to go further and replace obsolete aspects in teaching mathematical disciplines. This study must first prove theoretically, and later experimentally, that, firstly, there are still problems in the "modern" teaching method, and secondly, they have solutions that can be implemented on the basis of any education institution by the forces of teachers working in it. Of course, within the framework of one work it is impossible to consider all the issues that are available, therefore we have analyzed only a few, which in our opinion are most suitable for an immediate solution. The section "Combinatorics" was chosen by us as statistically containing the 
greatest number of issues difficult for students to quickly understand, on several of which we will try to give an exhaustive comment.

Key words: combinatorics, problem, education institution, element of combinatorics, conditions of existence

удк 373.3.015.31:502/504]:37.064.1

\author{
Алла Колишкіна \\ Сумський державний педагогічний \\ університет імені А. С. Макаренка \\ ORCID ID 0000-0001-9598-1830 \\ Катерина Врадій \\ Сумський державний педагогічний \\ університет імені А. С. Макаренка \\ ORCID ID 0000-0003-2991-7771 \\ DOI 10.24139/2312-5993/2019.08/086-098
}

\title{
ВИКОРИСТАННЯ ІГРОВИХ ТЕХНОЛОГІЙ У ФОРМУВАННІ ЕКОЛОГІЧНО ДОЦІЛЬНОЇ ПОВЕДІНКИ УЧНІВ ПОЧАТКОВИХ КЛАСІВ
}

у статті розв'язується проблема екологічного виховання учнів початкових класів. Мета дослідження полягає в обгрунтуванні ефрективності використання ігрових технологій у формуванні екологічно дочільної поведінки учнів початкових класів. Для досягнення мети публікації використано методику дослідження рівнів екологічної поведінки учнів початкової школи у природі, що складається з таких компонентів: 1) створення уявних ситуацій за допомогою серій завдань; 2) створення реальних ситуацій вибору взірия поведінки учнів початкової школи в природі; 3) спостереження за поведінкою учнів у природі. Розроблено змагальні, рольові та імітаційні екологічні ігри, що базуються на навчальному матеріалі, запропонованому шкільною програмою. Доведено, що гра екологічного змісту сприяє реалізації поведінкового потенціалу дитини щодо природи, забезпечує осмислення власної діяльності у природі. Перспективи подальщих наукових розвідок пов'язані з дослідженням проблеми формування екологічно доцільної поведінки як чинника соціалізації учнів початкової школи.

Ключові слова: екологічно дочільна поведінка, екологічне виховання, дидактичні ігри, рольові екологічні ігри, імітаційні екологічні ігри, учні початкової школи, рівні екологічної поведінки, поведінка.

Постановка проблеми. Екологічні проблеми в наш час набули глобального характеру, досить гостро вони відчуваються і в Україні. Вирішення таких проблем відбувається на різних рівнях - державнополітичному, економічному, науково-технічному, культурно-освітньому. Вагомим у цьому зв'язку постає саме культурно-освітній чинник, адже основні причини екологічної загрози пов'язуються з антропоцентричною свідомістю людей, з їх переважно споживацьким ставленням до природи, стилем діяльності й поведінки в довкіллі. Особливе місце в системі екологічної освіти та виховання належить початковій школі. Саме цей 